\title{
Monetarism and the Battle with the Global Economic Crisis
}

\author{
Prof. dr hab. Jan Komorowski ${ }^{1}$ \\ ${ }^{1}$ Institute of Finance, Warsaw School of Economics, Warsaw, Poland \\ Correspondence: Prof. dr hab. Jan Komorowski, Institute of Finance, Warsaw School of Economics, Poland.
}

Received: May 25, 2015

Accepted: September 21, $2015 \quad$ Online Published: October 22, 2015

doi:10.5430/ijba.v6n6p36

URL: http://dx.doi.org/10.5430/ijba.v6n6p36

\begin{abstract}
The purpose of this article is to research and verify the hypothesis that the current crisis is the result of monetarist doctrine and it concludes that up to now the battle against the International Financial Crisis is ineffective regarding policy effects and unsatisfactory concerning methods.

After a period of growth and prosperity, we are now in the final stages of a more than 30 years long era of monetarism. It is observed how the system defends itself from falling. However, at the same time, the fight against the crisis is dominated by monetarist instruments. Low evaluation of the effectiveness of this fight leads to the conclusion that it is impossible to fix the economy using the same methods that led to the crisis outbreak.

After six years since the crisis outbreak the condition of the economy demonstrates the low effectiveness of dealing with the crisis and the further intensification of the crisis-factors. The end of the monetarist age signals the need to seek systemic solutions, new approaches to quality management and change the way of thinking, which seems to be necessary for the Western economy to get out of recession.
\end{abstract}

Keywords: monetarism, international financial crisis, financial policy, quantitative easing policy

\section{Method}

1) The article is a consequence of the research problem, which is expressed in beginning of the text. It concerns the contemporary stage of the Global Economic Crisis and the efficiency of the faith with its negatives.

2) The author formulates the purpose of this article and puts the main hypothesis intending to explain it by a research and verification. The domain of research is in the science of Economics, discipline: Finance, field: Public Financial Policy.

3) The research contents six paragraphs presenting the complexity of the problem presented in a logical sequence starting from empirical presentation of the problem, theoretical base of the analysis and dispute fundamentals of a contemporary public financial policy, descriptions of the action against the crisis taken by the main international centers of financial policy, its consequences and finally, a short dispute on practical dilemmas.

4) The content of the article is concluded by the summary, which includes the author's final comment and the list of six theses enclosed.

5) The main methods of research are the descriptive analysis and comparative analysis presenting the researched problem in multidimensional and interdisciplinary approach.

6) The sources of the article are based on theoretical background and expertise knowledge, public reports and statistics, easy access internet sources and publications of the author.

\section{Results and Discussion}

\subsection{The State of the World Economy Six Years after the Crisis Outbreak}

Economic policies at the state level, as well as programming the behavior of entrepreneurs in the market, require clear perspectives. Without a clear diagnosis it is difficult to move in the world of business. The key issue is whether we still have to deal with the crisis and what factors contribute to it, or whether the end of the crisis can already be talked about. There is no doubt that "crisis-end advertisement", "greetings from the stock exchange" and other media treatments, repeated many times to the public, but unsupported by hard evidence, are unreliable. 
A deep crisis of the western economy is a fact. A sense of helplessness and lack of control over the situation development dominated our thoughts. Events that directly led to the outbreak of the crisis are now irrelevant. Nowadays, major problems, such as a wide range of imbalances, economic stagnation, the dynamics of debt, the scale of public expenditure, excess liquidity in the financial markets, the scale of speculation, lack of confidence in the financial sector, and the clash of interest and currency zones are occurring with greater intensity. The mood in the financial sector is such that, at any moment, another eruption may occur.

Recognizing the absolute dominance of the financial sector over the non-financial sphere, i.e. the "financialisation" of the western economy, it seems that the crisis in the real economy is occurring in the background. The decline in industrial production, processing of raw materials, as well as other raw materials such as the mining sector, is interpreted as an expression of the elimination of low-margin industries. Facing such problems, according to the monetarist doctrine, the liberal state cannot interfere and consequently jobs are shrinking, unemployment remains high amongst the young and the stagnation of industrial production deepens. The scale of bankruptcies, suicides, financial scandals, economic crime, junk contracts, homelessness and other pathologies are the reality of life, which is not always reflected in the statistics (Note 1)

The monetarist way of thinking about the economy affects the choice of anti-crisis instruments. There is a belief that it is sufficient to lead to a recovery in the financial markets to bring the real sphere back into an equilibrium. Particularly amazing is that the attention of economists is focused on a short-term financial balance, rarely the fundamental issues relating to the structure of the economy are taken, concerning the security of raw materials, loss of industry, debt accumulation, dependency from abroad etc.

It is not true to say that the crisis is global. Against this background, a successful development strategy of the Far East is shocking. The crisis touches this region only in the sense that the demand decline in Western countries reduces economic growth in the East, which, nevertheless, is impressively high. China, which takes the first place in global production, is the real tycoon in 'showering'their goods all over the world. It is hard not to notice the dominance of Chinese banks, the accumulation of foreign exchange reserves, export expansion, technological advancement, the momentum of public projects, the scale of luxury goods, works of art, and automotive markets. (Note 2)

The status of the most dynamically developing region provides a promotion of the Far East from the imitation phase to the era of economic and technological dominance. The financial opportunities, accumulated surpluses, domestic demand, a high rate of accumulation, the scale of public investment, scientific and technical progress are completely underestimated.

Depreciating these achievements causes a lack of interest in a number of innovations in the economy of the countries in this region that could be implemented for the benefit of the West. There is no doubt that the main barrier to understanding the causes of the achievements of the Far East is the ideological struggle and monetarist way of thinking. Unfortunately, the "brake" on the world economy is the West.

\subsection{Monetarist Thinking, as a Brake on Overcoming the Crisis}

In fact, many people, including scientific authorities, especially "Chicago School" enthusiasts, just do not see the connection between monetarism and the crisis. It is not about theoretical issues and a model of the economy, but the long-term effects of monetarist economic system. The increasingly visible collapse of the economy, debt accumulation and life at the expense of future generations means that the link between the theory of monetarism and economic reality is the same as the relationship of the theory of socialism and the practiced socialist economy.

Monetarist theory appears in the publications in the fifties due to Milton Friedman. Initially, the concept which is the negation of Keynesianism focused on the study of the effects of monetary policy on national income. Further theoretical work has contributed to the economic development of the school as an alternative to the Keynesian welfare state, the implementation of which has come to the end of its possibilities at the end of the $70 \mathrm{~s}$.

In the early eighties, the doctrine of monetarism became the basis of the reforms of Ronald Reagan (1981) and Margaret Thatcher, and then spread to most of the western countries. Thus begins the over thirty-years-long era of monetarism in the economy. During the booming period in the nineties, monetarism creates a dynamic business environment based on liberal principles and deregulation of the capital market. This system is based on a specific philosophy of thinking, which is dominated by the pursuit of money, resulting from the conviction that "cash counts" and "real money is earned on the stock market."

It is worth noting that the systemic transformation of the Polish economy in the 90s, coincided with the flowering phase of monetarism, which means that the transformation that has taken place in Poland through reforms of Leszek Balcerowicz and Jeffrey Sachs, consisted in the construction of the economic system and monetarist way of thinking, which led to a fundamental redefinition and new conflicts. 
Table 1. The most important references of monetarism category

\begin{tabular}{|c|c|}
\hline Economic Theory & $\begin{array}{l}\text { Idea, concept, current research, and economic school launched in } 1956 \text {. by M. } \\
\text { Friedman, developed by A. Schwartz, K. Brunner and A. Meltzer, M. Parkin, A. } \\
\text { Walters, D. Friedman, K. Ohmae and others associated with the analysis of the } \\
\text { impact of money supply on the economy and national income through the control of } \\
\text { interest rates and Treasury bonds. This concept implies the effectiveness of market } \\
\text { mechanisms and rejects the direct participation of the state in economic processes. }\end{array}$ \\
\hline Economic Doctrine & $\begin{array}{l}\text { The doctrine is based on the use of the money supply as a determinant of economic } \\
\text { activity within the mechanism of functioning of the money market and capital } \\
\text { market, treats capital as a major factor in creating value, rejects Keynesian solutions } \\
\text { as ineffective in an open market economy and globalization, so it is a doctrine } \\
\text { opposed to the state intervention doctrine. }\end{array}$ \\
\hline Economic Policy & $\begin{array}{l}\text { The choice of policy instruments to ensure the implementation of the economic } \\
\text { growth policy through the money supply control method by the state monitoring of } \\
\text { the money market functioning in conjunction with the liberal economic policy } \\
\text { assuming currency convertibility, removal of restrictions on the movement of capital, } \\
\text { strengthening of free trade, deregulation of the economy, promoting individual } \\
\text { entrepreneurship. }\end{array}$ \\
\hline Financial System & $\begin{array}{l}\text { Includes general characteristic of monetarism regulatory and financial institutions } \\
\text { regarding the mechanism of supply and functioning of the money in the financial } \\
\text { markets and its impact on business processes. A key role in this system perform } \\
\text { international banks, investment funds, insurance companies and other financial } \\
\text { corporations, which act as an intermediary between the representatives of supply and } \\
\text { demand on the individual financial markets. The impact of the state on the financial } \\
\text { system is indirect through legal standards, regulators and supervisors. }\end{array}$ \\
\hline Economic System & $\begin{array}{l}\text { Monetarist approach of modern economic relations is based on the functioning of the } \\
\text { capital market institutions and money market funds that support the functioning of a } \\
\text { non-financial sphere, i.e. the real economy to businesses and households. The center } \\
\text { is a capital market, which combines the financial sphere and the real. Its dynamics } \\
\text { illustrates economic development, cash flows, distribution of capital, investment } \\
\text { trends, the level of return and cost of capital. In a liberal economy the state's } \\
\text { economic policies, including fiscal and budgetary policy are losing its importance. }\end{array}$ \\
\hline $\begin{array}{l}\text { Economic Age, } \\
\text { Sense of rationality, } \\
\text { Common practice }\end{array}$ & $\begin{array}{l}\text { Initiated by R. Reagan, the US president, in 1980, expressed in the 'financialization' } \\
\text { of the economy, which is subordinated to the economic and financial } \\
\text { decision-making mechanism processes. Separateness of this era refers to the } \\
\text { characteristic way of thinking about the economy based on the interpretation of } \\
\text { business processes from the perspective of the functioning of financial markets and } \\
\text { monetary developments. On the assumption that capital is the dominant source of } \\
\text { value, according to the belief that "money makes money on the stock market", the } \\
\text { flow of capital determines economic development, and its outflow causes a } \\
\text { recession. This era is characterized by higher growth rate of capitalization of the } \\
\text { economy of the GDP. As a result of the financial sphere detachment from the real } \\
\text { economy, excessive money supply, the accumulation of debt and financial } \\
\text { imbalances, in } 2008 \text {, the global financial crisis erupts, announcing the twilight of the } \\
\text { era. }\end{array}$ \\
\hline
\end{tabular}

Source: Own Elaboration

Currently, the sense of monetarism is slightly different from the original theoretical assumptions in relation to the experience of economic policy, financial market regulation and supervision of financial institutions. The solutions adopted in different countries shows that monetary policy can take different forms, ranging from conservative and cost-effective policies aimed at the effect of "strong currency", as in the case of Switzerland, to the active support of the economy by the budget deficit, as in the US and Japan. 
What unites all monetarists is the aversion to intervention of the state and reduction of its presence in the economy, simultaneously with a belief in efficiency of the market mechanism and economic liberalism, and assigning of the specific role to the monetary processes and financial capital. In the long term such a thinking has resulted in a buildup of imbalances until the outbreak of the crisis in 2008. (Note 3)

In fact, monetarism has contributed to the development of the cult of money and the desire to get rich. According to this idea any good should be commercialized and reduced to monetary value, because striving for wealth surpasses all other values. Monetarist thinking is an expression of commercialization of social services, arts, education, health, welfare, safety, the prison, etc., which impoverishes the social content of these spheres of activity. Monetarism, as the ideology of radical capitalism is inherently inconsistent with the principles of the social market economy, the idea of solidarity and the balance between public and private interests, rooted in the values and traditions of Europe. Awareness of these properties, which depreciated monetarism, can be helpful in the search for ways out of the crisis.

\subsection{Monetarism as an Economic System}

The theory of monetarism assumes in general that, in the environment of the open market economy, control of currency stability and preventing inflationary processes are effective methods of maintaining economic balance. Stimulating the economy with instruments of monetary policy ensures economic growth in the long run. It is assumed that the supply of money causes an increase in consumer spending and investment, which further enlarges national income contributing to increasing needs and increased expenditure which leads to an increased standard of living.

Monetary policy comes down to the proper correlation of money supply increase and economic growth. Highly leveraged banks based on treasury debt instruments deliver capital to corporations which strive for the highest possible rate of return. The mechanism of capital supply for the private sector grants entrepreneurs access to capital at the lowest possible cost. The key aspect here is maintaining attractive; investment encouraging interest rates for both investors and borrowers (Note 4).

A crucial instrument that helps to implement this theory into practice is the supply of treasury bonds affecting the level of interest rates that is the price level of money on the financial market. In a liberal country such a mechanism drives the development of the financial sector. Areas of capital supply and interest rates through which a country stimulates economic growth is under control. The development of the capital market becomes the aim of monetary policy and its primary task is to maintain interest rates which ensure attractive return on investment which further encourages continuity of investment and keeps demand on the capital market at a reasonable level. As a result the issue volume and the rate of interest of treasury instruments are the main regulators of the capital market.

Winding up the business cycle solves a number of economic problems and this is why various tasks of budgetary institutions connected with increasing wealth and the standard of living within society are not so important for the government. The work of the international financial market based on monetarist doctrine has a systematic character. In the borderless economy the crucial role is played by financial institutions that fulfill functions as a center of the international financial system servicing peripheral countries in addition to the system. The center of the system issues world currency and controls both the creation and distribution of capital. As a part of the world financial centre there operates various institutions such as investment banks, stock exchanges, rating agencies, consultancy corporations and agencies of research and creating opinions.

Each new issue of debt securities, stimulates capital supply, helps reduce interest rates and accelerates the economy. The placement of new issues on the market stimulates the export of capital which helps overcome the limited demand in the internal markets. Introduction of treasury debt instruments recognized as risk-free to the world circuit of money becomes a form of subsidization of the country's economy by foreign creditors of the issuer. A country with monetary sovereignty may benefit from a low-cost source of financing for budgetary expenditure provided that excessive debt is prevented. The condition for the continued operation of this mechanism is to maintain control over the supply of instruments with the demand of the peripheral countries.

\subsection{Long-term Effects of Monetary Policy}

Long-term effects of increasing money supply are not so obvious. Who can predict the cumulative effects of 'empty money' and 'shaken relationships' in the real economy? Implementation of the doctrine of monetarism in the eighties and nineties was a period of rapid worldwide expansion of the capital market. Comparison of long-term trend in money supply and GDP shows a downward trend, reflecting the adverse consequences of this policy. It is continued by declining productivity of capital, rising operating costs, progressive uncontrolled accumulation of debt and deterioration of the other macro - indicators. 
Initially, with the high demand for capital and the international role of the US dollar, external funding opportunities for budgetary expenditures seemed unlimited. With this doctrine in the nineties, high supply of financial assets stimulates capitalization of stock exchanges. International capital flows are significantly ahead of the dynamics of international trade and industrial production. Rapidly increasing growth of financial assets, seen at the stage of 'bloom', results in the giant enlargement of savings by fast - growing and rich societies. This is the time, when a period of dislocation of industrial production to the Far East and the capital-intensive infrastructure programs, defense and social services begins. The broad stream of capital revives stock exchanges, the expansion of multinational corporations, and individual and public consumption on credit.

These processes create risk for local economies resulting from the system (e.g. Swiss Franc). With an excessive money supply easy access to the capital or its speculative flows can seriously distort the market mechanism, disorganize valuations and the calculation of the cost destroying entire sectors of the economy. Sense fades, risk becomes elusive, leading to what happened in Greece. Monetarists tend not to see the effect of increasing the amount of money on its quality, as well as recidivism of crossing the state budget expenditure above a safe level for long-term economic security. This is what happens in most EU countries, in which the budget deficits financed by a high debt increase will lead to a decline in GDP.

Reducing the demand for capital due to a decrease in productivity does not mean the loss of activity of banks on the money supply side, moreover it does not prevent them from engaging in high-risk investments. Limited demand of the domestic markets for the issues of treasury debt instruments leads to the distribution of these instruments in international financial markets. Banks manage the potential for the money creation driven by magnified deposits through the internationalization of operations. All this leads to an increase in market capitalization. Finally, low interest rates attract foreign expansion, while it seems that cheaper capital makes the economy more competitive, which is not always true.

Cheap capital and easy access to sources of financing, encouraging borrowing,-has placed many countries, companies and households on the brink of insolvency. The increase in bank debt does not mean that debtors are able to earn on leverage. There was a number of spectacular collapses of the financial markets on this background in the nineties such as in Russia, Argentina, Brazil, Mexico, Chile, and then in Iceland, Greece, Cyprus, Ireland, Portugal, Spain and Italy. As a result, capital markets shrank, the price of securities decreased significantly, debt refinance collapsed and the activity of enterprises decreased. These phenomena led to a deep recession, higher unemployment and hindered the in-flow of external capital.

\subsection{The Limited Effect of the Monetarists' Approach to Fight the Crisis}

In general, the fight against the crisis has not brought any significant effect. What is present, is the unstable equilibrium threatened by numerous factors, including the influence of fluctuations of exchange rates and interest rates, which in consequence might lead to another snowball effect. This is why governments do not present their willingness to take more significant measures in order to stimulate their economies. Symptomatic is the fact that the approach to fighting the crisis is limited to the monetarist array of instruments, which confirms the way of thinking about the economy. Postponed fiscal reforms, budget savings as well as high unemployment bring dissatisfaction among the electorate and lead to destabilization of the political situation. The lack of attractive alternatives leads investors to purchase treasury bonds, which on the other hand does not create any real economy effects.

According to the IMF's prognosis, the crisis is going to last until 2018, which is the length of the period needed to reduce the indebtedness of the public sector, which slows down the economy. However nothing is done in this dimension and what is more, the IMF recommends an increase in spending. The United States were the first to introduce the 'Quantitative Easing' program, and also started to reduce interest rates in order to fight the recession. On a monthly basis, the FED was buying huge amounts of debt securities (officially 80 billion of US. Dollars a month, however in practice, the scale of the operation was much bigger). The growth of stock indexes in the US, for many months has been indicating the end of recession. As a consequence, the policy of 'Quantitative Easing' was slowed down. According to certain press releases, the era of crisis is overcome and the forecasted economic growth is announced, however this boom does not affect any other area of the economy, apart from the financial sector. During the last six years since the beginning of the crisis, the indebtedness of the US doubled but at the same time almost no real benefit was achieved. Unnecessary bureaucracy developed along with numerous regulations and a tax burden which has doubled.

Exactly the same approach is introduced by the Central Bank of Japan (CBJ), with only one difference. The scale of the operation is at the level of $17 \%$ of the country's GDP. Time shows that the easing effect is short-lived and costs are high. According to the wire from the Japanese stock exchange, 'the miraculous influence of the printed money on 
indexes, starts to lose its strength. Although the central bank continues to supply money, the Japanese stock exchange notes a significant decline in stock prices and is compared to the effect of the nuclear power plant catastrophe in Fukushima or to the Tsunami disaster.

A similar situation takes place in the European Union, where investors do not perceive the current economic situation, at least in a positive light. What is more, the low level of economic activity in different sectors does not presage any breakthrough. However, analysts seem to be looking forward to the moment; when this trend will be reversed. Everyone is waiting for the EU's support, however this is likely to be too little to increase the profitability of the financial sector. It is postulated that "money will be dropped from helicopters". According to John Muellbauer, the Oxford professor, the governments would stimulate demand by sending a check for 500 euros to every adult citizen. Similar treatment for Europe is recommended by J. Stiglitz, who notices the correlation between the difficulty of overcoming the crisis with the reduction of a country's spending, the policy of savings and penalizing excessive spending. The economist claims, that the EU's approach to increasing public spending is too tentative.

The helplessness of monetarists extends to the point where it becomes contradictory with common sense. The anecdotic idea of Milton Friedman to drop money from helicopters might be modified by the author of this article. He suggests that an injection of fake money to the market might boost demand, but will not increase the level of debt! The thing is that the idea of Friedman is not about increasing the level of demand or employment in factories. Monetarists dream about the increase of capitalization of financial assets. They believe that they are in possession of the "philosopher's stone' metaphorically, so they have the patent to increase the value of financial capital by increasing the amount of money in circulation. As a consequence they print more and more, totally forgetting about the side effects in the future.

While the IMF operates according to this strategy, doubts are rising, whether there is anyone who is responsible for the whole situation and how far the financial system can go? This policy of the ECB is mainly encouraged by the top economist of IMF, O. Blanschard: “... We need to do everything in order to increase the demand and keep the growth, having in mind accommodative fiscal policy, recapitalization of banks or structural reforms... adjustments in the euro zone require lower prices in indebted countries in the South and simultaneously higher prices in core countries of the EU... it is recommended that German inflation will be higher and the purchasing power will be strengthened by the increase of real wages."

Without conviction the ECB decides to introduce the 'Quantitative Easing' program, because it is hardly proved that the program will be effective. The program of easing will be accomplished by the EBC during the period of 18 months until September 2016. Within this program 60 billion euros will be printed per month and supplied to the market. In this way ECB is going to increase its monetary base by $7.6 \%$ of GDP, which might stimulate bank credits. The increased money supply is expected to increase the rent ability attraction of financial instruments, enhance the attractiveness of investment in euros and protect the euro zone from the external inflow of capital, however this seems to be only a theoretical assumption. This QE policy, however originates from the will to prevent the euro from appreciation. It seems that IMF encouragement of QE only brought more trouble to the EU. In practice, deflation and negative interest rates became a nightmare for the EU, Switzerland and Scandinavia. It is estimated that in the European market, the number of debt instruments with negative profitability is twice as many and the new program will only aggravate the situation.

Deutsche Bank is of exactly the same opinion, when it comes to the low efficiency of the easing policy. It is thought that it will be extremely difficult to stop this tendency in the future. As a consequence of printing money, its amount increases demand and stimulates investment to a very small degree. As it is proved by researchers, a multiplying effect in the EU is totally out of the question, while in more developed countries people have more savings than liabilities. While the profitability of bonds is diminishing, more funds go to wealthier people, who have assets whose value increases, as a consequence of the easing program. It means that additional money turns into an asset on a financial market, which like a "black hole" attracts capital.

Deflation and negative interest rates are a totally new phenomenon. Low interest rates do not stimulate credits, but lead to a situation where business entities try to avoid financial services and where we can observe a diminishing demand for money and financial services. Over-liquidity is reinvested on a speculative market. Here anything might happen. The excess of financial instruments is never accompanied by inflation, which means that the monetary and capital markets are merged, so the warning factors and the barometer of the quality of money are lost.

Everyone forgot about the concept of two speeds in the EU. Extremely low interest rates, lack of clear vision for the future of the EU, which, while penalizing Hungary's experiments, discourages others from initiatives. From the perspective of integration enthusiasts, like Poland, actions taken by the EU are unclear and strongly discourage them 
from joining the European Monetary Union. Turning points are the right time to evaluate the strategy of the EU and to define the role of the ECB, because it is becoming a more common belief that the reputation of the Union's institutions is diminishing and more often these institutions are recognized as the cause of disintegration.

\subsection{The Need of a Broader Perspective on the Crisis}

Admittedly, the condition of the Polish economy is relatively good, promising the maintenance of GDP growth above $3 \%$, therefore the Polish National Bank, likewise Polish economists approach the problem of qualitative easing with common sense and moderation. It can be seen at a glance that the temporary measures are of limited effect, hence, more important are the structural determinants of the economic situation (Note 5).

As demonstrated by Prof. R. Szewczyk, a monetary policy of increasing the amount of money in the market destroys its basic functions, and setting the interest rates does not have much in common with the market economy. The proponents of the short-term balance deplore the negative effects of stagnation on the market, completely blind to the other scenarios. They encourage the loosening of monetary policy without worrying about the consequences of future accumulated debt, how much bonds will be worth, how to secure the pension funds or to issue more debt securities with no chance of repurchase. (Note 6)

In the context of the crisis, a political scientist at Oxford, Professor J. Zielonka, draws attention to the build-up of the financial crisis by the crisis of the market economy and democracy. The vanishing of the state and its economic functions is observed. Financial markets are not conducive to socio-economic development, but have become an area of speculation, as well as criminal activities. Political parties no longer serve the development of democracy, but instead they enforce the distance between the area of public authority and a citizen. This is related to social processes of a crisis, unemployment, demography, the depreciation of work, the "rat race", consumerism etc. (Note 7)

Limiting the crisis only to a financial dimension cannot be done; one of the reasons is its effect of imbalance and shrinking of the economy. Stimulating the economy through the supply of money, debt, public spending, fiscal policy, induces limited effects in the real economy. Therefore, all recovery programs written from the perspective of money supply and expenditures of the state are not original and bring limited results (Note 8).

\section{Conclusion}

When approaching the economy, the monetarists tend to operate on a limited amount of variables while simultaneously not doubting the efficiency of the market, which gives them the illusion of predictability of the situation and ease of forecasting. The veracity of the assumptions presented in the introduction is important from the point of view of the consequences of the global economy and EU perspective. The monetarist approach to economic problems does not show premises of the end of the economic crisis in the Western world, but of creating illusion of economic and social stability. Arguments presented in this paper lead to the following conclusions:

1) As a result of "financialization" of the economy, expressing the dominance of the financial sector over the non-financial sector, we exhibit a direct casual link carrying the crisis in the financial sector to the real economy.

2) A false interpretation of the crisis can be noticed as an objective, global and homogenous phenomenon etc. which should be surrendered, leaving the initiative to the strongest to solve it.

3) Monetarist financial policy tools result in the lack of effects with fighting the crisis with methods that originally have led to it. Everything seems to indicate that the majority of countries follows consciously the footsteps of Greece. The future looks pessimistic.

4) There is a futility of monetarist ideas to combat the crisis and protection of the financial sector at the expense of the real economy. Therefore, it is impossible to restore equilibrium in the real economy under the slogans of the fight against the financial crisis.

5) So far the financial crisis has not violated the financial pyramid, which is growing at an alarming pace. Frightening are the possible effects of its collapse, on a larger scale than in the case of Greece, as there is no possibility of state aid on such a scale.

6) In this context, the most dangerous is the global speculation fueled by the supply of money. Lack of control over the market of short-term investments and derivatives markets that was originally designed to secure transactions, in macro scale has incalculable destructive potential, disorganize local markets and when provoked, can at any time capsize the financial pyramid.

As studies confirm, an increase in the amount of money, whether through deficit, public spending, quantitative easing, bank recapitalization, or spending cash from "helicopters", brings effects that are short-term and are 
disproportionate to the costs, which are postponed in time and accelerates the accumulation of debt, insolvency of states, depreciation of pension funds, life at the expense of future generations and debasement. Holders of debt assets, investment and pension funds are participating in a giant pyramid scheme, and so far, are benefiting from the fictitious wealth, which in a blink of an eye can be dematerialized.

Adding money into the circulation, as a cure for all diseases, increases the gigantic debt pyramid. Money without coverage is like a drug, which gives short-term relief, is addictive, has decreasing effects, and in addition, accumulates in the organism. Overdose of medicine makes it a poison, which can cause unpredictable results. One gets the impression that the sick economy was entrusted not to doctors, but rather to some alchemists, who at any moment could cause an explosion.

\section{References}

Blanchard, O. Retrieved from http://biznes.gazetaprawna.pl/artykuly/651954

Misiąg W. Budgetary consequences of the world financial crisis, Retrieved from www.e-finanse.com/artykuly/125. www.naszdziennik.pl/mysl/107115

Ostaszewski, J. Finance, Difin, Warszawa 2013.

Quantitative easing, or how to fight essectively with deflation, 11.01.2015.

Retrieved 22 September 2014, from http://wgospodarce.pl/informacje/16388

Retrieved from Gramm P., Tego jeszcze nie było: wydać tak dużo pieniędzy, aby wyprodukować tak mało dóbr!

Retrieved from www.forbes.com/sites/nathanlewis/2015/01/22/helicopter-money

Retrieved from www.nbp.pl/polityka_pieniezna/dokumenty/minutes/mi_iii2015.pdf

Retrieved from www.obserwatorfinansowy.pl

Retrieved from www.pb.pl/4039017,79522, friedman-ebc-szybciej-wyhamuje-qe

Retrieved from www.szewczyk.net.pl/assets/files/pliki/Obliczedlugu.pdf

Retrieved from www.zerohedge.com/news/2014-11-21/deutsche-bank

Stiglitz, J. Lack of rationality in Europe. Retrieved from www.obserwatorfinansowy.pl/

The end of Japanese eldorado?, Bankier.pl, 11.04.2014.

Zielonka, J. The End of the European Union?, PISM, Warszawa 2014.

\section{Notes}

Note 1. The scope of junk labor contracts continues to expand. Youth unemployment and the scope of social assistance takes a dramatic scale. In the US, food stamps are used by 49 million people.

Note 2. The public is not aware of the fact that China produces 15.5. Million cars per year, i.e. more than five times more than the US (2.9 million.). Concentration scale of industrial production of other goods in China is even greater.

Note 3. The characteristic expression of monetarism is the recognition of all the processes in terms of benefits rather than other values. For example, a work of art is only worth what someone will pay for it, a patient is worth for healthcare as much as hospitals can earn money from him or her, to seek justice does not make sense when the costs of law enforcement exceed the amount of damage, etc., which in essence means affirmation of lawlessness, the subordination of art to the strength of money, medical care reserved for the rich, and so on.

Note 4. This doctrine has contributed to the global expansion of the financial markets, strengthened the position of the US dollar as the world's leading currency and brought the greatest impact on the domestic economy during the reign of President Ronald Reagan in the eighties of the last century, and then became the basis for economic success in the UK during the exercise of power by Margaret Thatcher. More on this topic in the "Finance" red. J. Ostaszewski, Ed. Fifth, expanded, Dyfin, Warsaw 2010, pp. 71-73.

Note 5. Page: http://www.nbp.pl/monetary politics /dokuments.pdf

Note 6. Page: http://www.szewczyk.net.pl/assets/files/pliki/ The face of debt.pdf

Note 7. Book: Por. J. Zielonka, The end of the European Union?, PISM, Warszawa 2014

Note 8. Paper: W. Misiąg, Budżetowe skutki kryzysu światowego systemu finansowego, www.e-finanse.com/artykuly/125.pdf 